\title{
Design and testing of agricultural waste fired copra dryer
}

\author{
S.V. PATIL* AND N.J. THAKOR
}

Department of Agricultural Process Engineering, Dr. B.S. Konkan Krishi Vidyapeeth, Dapoli, RATNAGIRI (M.S.) INDIA

*Author for Correspondence

Research chronicle : Received : 01.04.2016; Revised : 24.04.2016; Accepted : 07.05.2016

\section{SUMMARY :}

Coconut plantation is abundant in konkan region of Maharashtra (India). Small landholders can improve their income through value added activities in downstream processing of coconut. One such activity would be to dry copra for preservation and subsequent oil extraction. Copra drying in konkan region is practiced largely through sun drying and chula drying. In both these drying methods, copra quality deteriorates significantly due to either open fire smoke, dust and mould growth in sun drying. There is need to have a natural convection indirect heating small mechanical copra dryer suited to the requirements of konkan farmers. This paper present design and testing of natural and forced convection indirect heating small mechanical dryer using agricultural waste as fuel. Components of dryer were drying chamber housing with two trays inside, heating chamber, burning cum heat exchanging unit i.e. furnace and chimney. The capacity of the dryer is $50 \mathrm{~kg}$ coconuts per batch (to hold coconut halves $50 \%$ (w.b.) moisture content). The dryer was tested for drying performance in respect of drying air temperature, fuel consumption and quality of dried copra after the drying. The total area required for housing the dryer is $0.81 \mathrm{~m}^{2}$. This is suitable dryer for drying of coconuts in rainy season when sun light is seldom available and chance of contaminants from quality point of view is minimum.

\section{KEY WORDS : Agricultural waste, Copra dryer, Coconut plantation}

How to cite this paper : Patil, S.V. and Thakor, N.J. (2016). Design and testing of agricultural waste fired copra dryer. Internat. J. Proc. \& Post Harvest Technol., 7 (1) : 73-78. DOI: 10.15740/HAS/IJPPHT/7.1/73-78 